Article

\title{
Evaluation of the Effect of Dolomitic Lime Application on Pastures-Case Study in the Montado Mediterranean Ecosystem
}

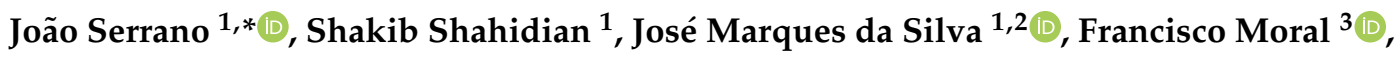 \\ Fernando Carvajal-Ramirez ${ }^{4}(\mathbb{D})$, Emanuel Carreira ${ }^{1}$, Alfredo Pereira ${ }^{1} \mathbb{D}$ and Mário de Carvalho ${ }^{1}$ \\ 1 MED-Mediterranean Institute for Agriculture, Environment and Development, Instituto de Investigação e \\ Formação Avançada, Universidade de Évora, Pólo da Mitra, Ap. 94, 7006-554 Évora, Portugal; \\ shakib@uevora.pt (S.S.); jmsilva@uevora.pt (J.M.d.S.); emanuel.ruben@hotmail.com (E.C.); \\ apereira@uevora.pt (A.P.); mjc@uevora.pt (M.d.C.) \\ 2 AgroInsider Lda. (spin-off da Universidade de Évora), 7005-841 Évora, Portugal \\ 3 Departamento de Expresión Gráfica, Escuela de Ingenierías Industriales, Universidad de Extremadura, \\ Avenida de Elvas s/n, 06006 Badajoz, Spain; fjmoral@unex.es \\ 4 Department of Engineering, Mediterranean Research Center of Economics and Sustainable \\ Development (CIMEDES), University of Almería (Agrifood Campus of International Excellence, ceiA3), \\ La Cañada de San Urbano, s/n. 04120 Almería, Spain; carvajal@ual.es \\ * Correspondence: jmrs@uevora.pt
}

Received: 28 March 2020; Accepted: 4 May 2020; Published: 6 May 2020

\begin{abstract}
The Montado ecosystem, predominant in the Mediterranean region, consists of poor soils, a sparse cover of cork and holm with an understory of natural biodiverse pastures, grazed by animals in extensive regime. The recommended procedure for increasing productivity of these pastures is based on the application of phosphate fertilizer. One of the main productivity-limiting factors is, however, associated with soil acidity. The objective of this work was to evaluate the simultaneous effect of the holm oak canopy and the application of dolomitic lime on the productivity and quality of a permanent biodiverse pasture, grazed by sheep, in an acid soil $(\mathrm{pH}=5.4 \pm 0.3)$. Pasture was monitored at the end of autumn 2018 and winter and spring 2019. The results show that amendment of soil acidity is a slow and gradual process that improves soil $\mathrm{Mg} / \mathrm{Mn}$ ratio and has a positive impact on pasture productivity and quality. Pasture crude protein availability $\left(\mathrm{CP}, \mathrm{kg} \cdot \mathrm{ha}^{-1}\right)$, which is based on both pasture dry matter yield $\left(\mathrm{kg} \cdot \mathrm{ha}^{-1}\right)$ and quality $(\mathrm{CP}, \%)$, proved to be a very practical indicator of the contributions of tree canopy and soil acidity correction to the holistic management of the Montado ecosystem.
\end{abstract}

Keywords: soil pH amendment; tree effect; productivity; crude protein; pasture quality index

\section{Introduction}

The silvo-pastoral ecosystem, predominant in the Alentejo region, is based on Cambisols whose genesis derives from granitic bedrock [1]. As a result of their origin, these soils have characteristics that make them not very fertile, due to their low organic matter content, the very high acidity, or even the reduced cation exchange capacity [2]. In the case of grazed soils, the tendency towards acidification is accentuated, not only by the accumulation of manure, but also by the extraction of nutrients and the leaching of nitrates [3]. On this soil substrate, natural biodiverse pastures develop under a canopy of cork and holm trees, while grazed by animals in extensive regime. The recommended procedure for the recovery of these soils is the installation of permanent pastures and increasing soil fertility through chemical fertilizer applications [4]. One of the main limiting factors of greater productivity 
is, however, associated with soil acidity, which raises the obvious question: Does the effectiveness of fertilizer application increase if, in advance, the soil $\mathrm{pH}$ is corrected?

In addition to soils of low fertility, the Mediterranean climate of these regions is characterized by great irregularity and seasonality, which imposes hot and dry summers and a high concentration of precipitation events in a relatively short winter [5]. Typically, dryland pastures in the Mediterranean climate are composed of annual plants, whose cycle begins with the first rains, in early autumn. Their growth takes place during the autumn, winter, and spring period [4]. After the reproductive phase, at the end of spring, the vegetative cycle ends, with the production of flowers and seeds; this allows these plants to survive the demands of the summer period [4]. The development and productivity of dryland pastures depend mainly on the distribution of precipitation throughout the year and on its combination with the air temperature. Additionally, the fall in temperatures in winter mainly affects legumes, which are less resistant to cold [4].

In addition to soil and climate, the effect of trees is also relevant to pasture growth and results from the deposition of biomass on the soil and the ensuing biological activity. This process has a positive impact on fertility and structure of the soil under the tree canopy, with an increase in organic matter, greater availability of nutrients, greater water retention capacity, and a slightly less acidic $\mathrm{pH}$ [2]. Pasture productivity under tree canopy (UTC) can be negatively affected as a result of competition for light, moisture, and nutrients [6]; however, the quality of pasture tends to improve, although this trend varies according to the level of soil fertility [7]. The improvement in crude protein (CP) levels UTC was justified by Pullanagari et al. [8] as a result of a reduction in the photosynthetic rate, and consequently a delay in the physiological development of the pasture UTC, as well as variations in the floristic composition [3]. The combination of these factors results in the plants remaining physiologically younger in the understory and, therefore, with higher metabolic levels for a longer period of time [6].

One of the most important decisions in the Montado management, prompted by the existence of usually poor and acidic soils, is related to fertilization and soil amendment [9]. The basic strategy for soil conservation, reversal of the degradation of this ecosystem, improvement of pastures productivity, and, consequently, of animal production begins with the correction of soil acidity [4]. Carvalho et al. [2] demonstrated the importance of ionic antagonism between soil concentrations of magnesium $(\mathrm{Mg})$ and manganese $(\mathrm{Mn})$ in crop productivity. They called attention to the interest of applying dolomitic lime to correct soil acidity since it simultaneously improves the $\mathrm{Mg} / \mathrm{Mn}$ ratio in the soil solution. This is followed by the correction of other possible deficiencies, such as the reduced availability of some nutrients, through the application of fertilizers. Legumes in particular can benefit from the acidity correction [10] but also from the application of phosphate fertilizers, which result in an increase in the total biomass production of the pasture [11].

The objective of this work, consisting of regular and systematic monitoring of the evolution of the pasture, was to evaluate the simultaneous effect of the holm oak canopy and the application of dolomitic lime on the productivity and quality of a permanent biodiverse pasture, grazed by sheep, in an acid soil.

\section{Material and Methods}

In this work, an experimental field of Montado (4 ha), located at Mitra Farm ( $\left.38^{\circ} 53.1^{\prime} \mathrm{N} ; 8^{\circ} 01.1^{\prime} \mathrm{W}\right)$, was monitored. The predominant soil in this parcel is classified as Cambisol, the major reference soil group in Portugal [2], derived from granite and characterized by low fertility, cultivated under a mixed, agro-forestry production systems [1]. These soils are generally characterized by their coarse texture (mostly sandy loam), small cation exchange capacity (CEC), organic matter content $(\leq 1 \%)$, and water holding capacity, and strong acidity $(\mathrm{pH} \leq 5.5$ in water) [2]. This ecosystem consists of dryland biodiverse pastures, Quercus ilex ssp. rotundifolia Lam. trees, and is grazed by sheep. During the experimental period, the whole field was occupied by adult sheep in maintenance, none of which were pregnant or lactating. The animals were kept on each of the plots in continuous grazing, at an annual stocking rate of eight animals per hectare. The sheep flock consisted of a mixture of Merino 
White and Merino Black breeds (Figure 1). Herd management consisted only of vaccinations and deworming according to the health management calendar, a hay supplementation during the autumn period, and a commercial protein supplement in the summer. The animals had permanent access to blocks of mineral salt with macro- and micronutrients.

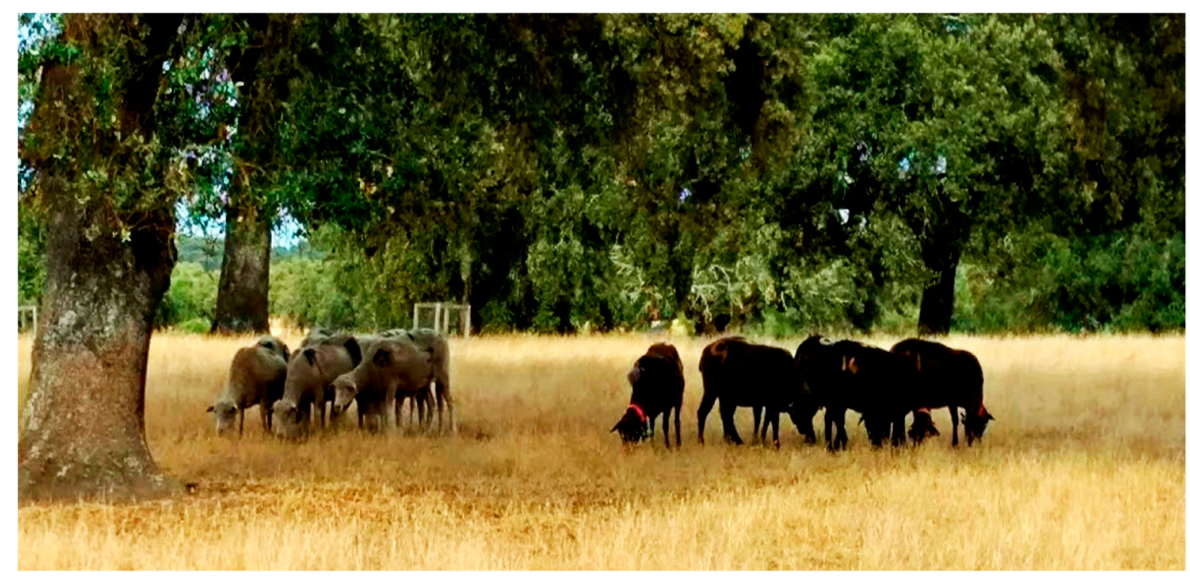

Figure 1. Sheep grazing under the tree canopies at the experimental field (end of the spring).

\subsection{Characterization of the Climate}

The Mediterranean climate is characterized by most of the rainfall concentrated in the winter and very dry, hot summers. The average monthly temperature varies between about $8^{\circ} \mathrm{C}$ in January and around $25^{\circ} \mathrm{C}$ in August, with minimum temperatures close to $0{ }^{\circ} \mathrm{C}$ between December and February and maximum temperatures above $40^{\circ} \mathrm{C}$ in summer. The annual accumulated precipitation in the region varies between 400 and $650 \mathrm{~mm}$, distributed mainly between October and March, and practically nonexistent in summer. Figure 2 illustrates the thermo-pluviometric diagram of the Meteorological Station of Mitra (Évora, Portugal). This figure shows the evolution of the monthly mean temperature and monthly rainfall between September 2018 and August 2019, and the average monthly rainfall in a 30-year period (between 1981 and 2020). In the agricultural year of 2018/2019 and relative to the normal average for the region, the figure shows a reduction of $60 \%$ in the monthly rainfall between December and June (148 $\mathrm{mm}$ versus $370 \mathrm{~mm}$ ).

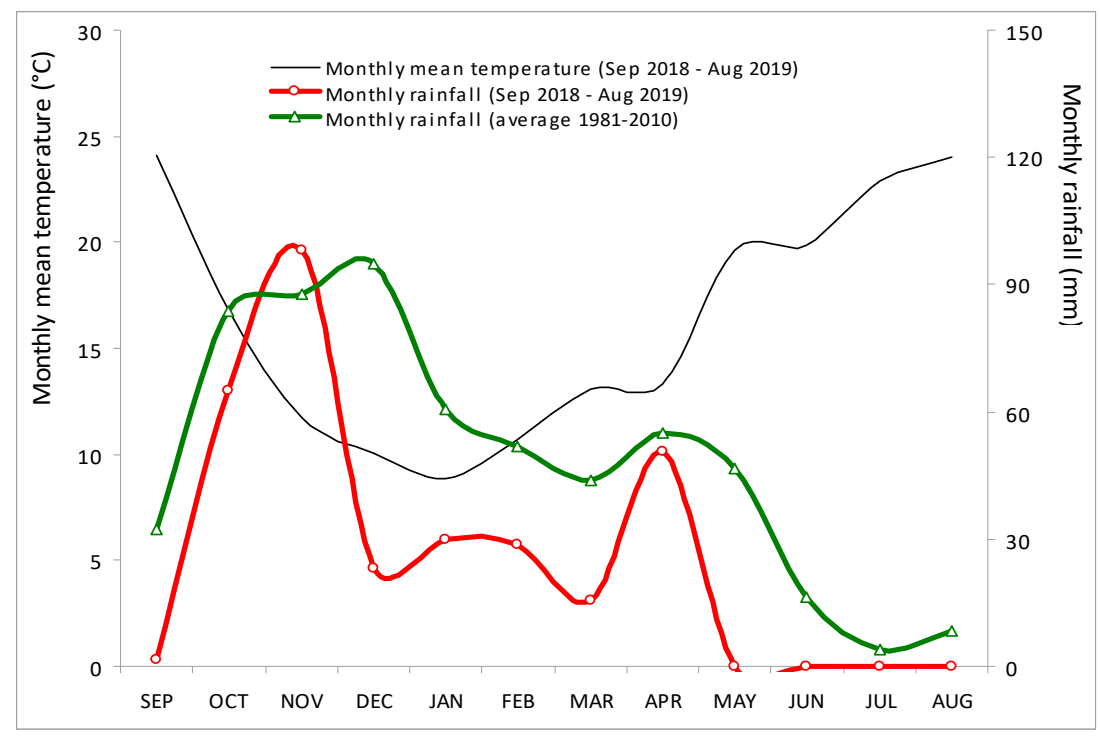

Figure 2. Thermo-pluviometric diagram of the Meteorological Station of Mitra (Évora, Portugal) between September 2018 and August 2019. The evolution of the average value of the monthly rainfall in a 30-year period (between 1981 and 2010) is also presented. 
Figure 3 shows the chronological diagram of the activities carried out between October 2015 and June 2019 for monitoring the effect of dolomitic lime application in pasture productivity and quality.

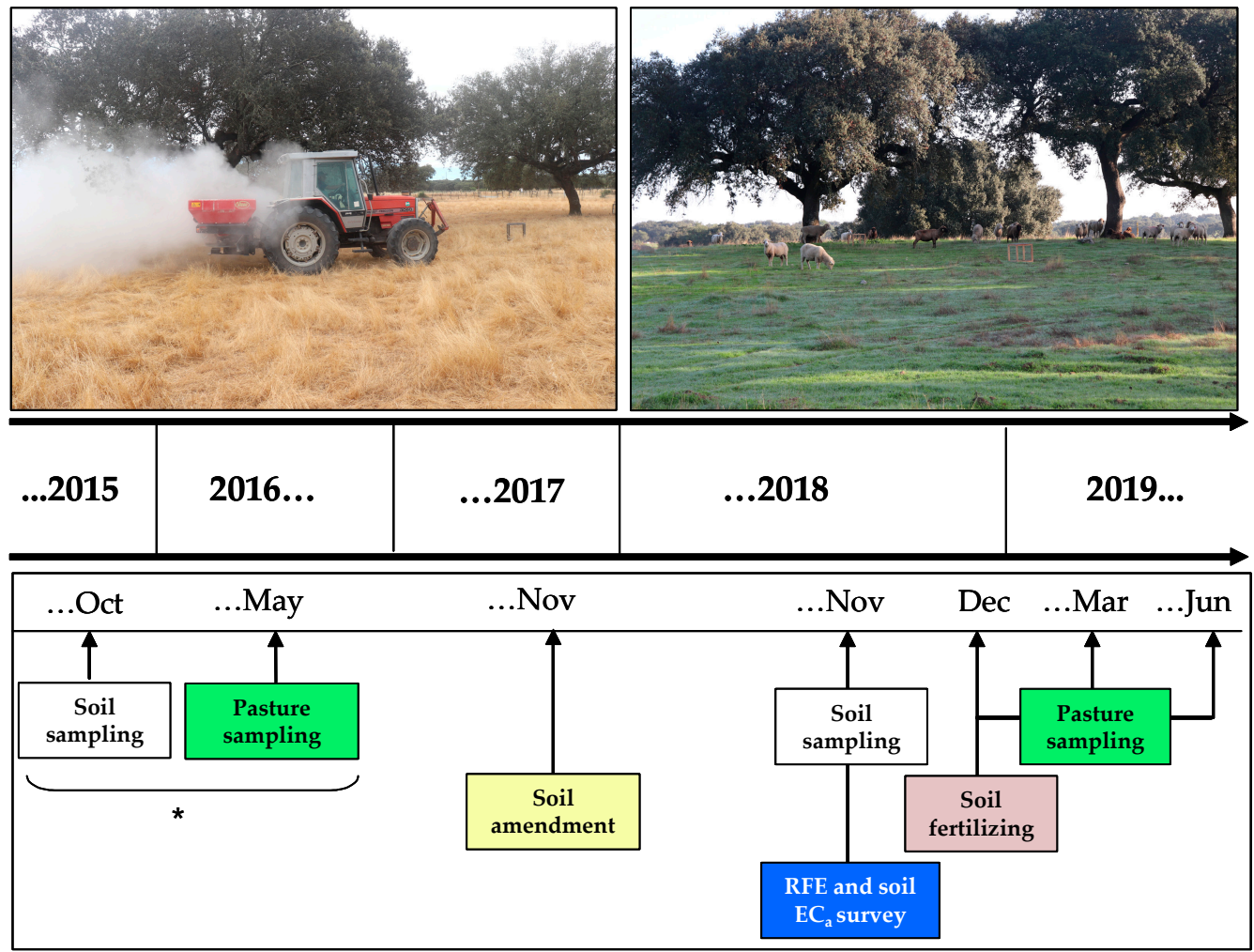

Figure 3. Chronological diagram of activities carried out between October 2015 and June 2019 at the Mitra experimental field for monitoring the effect of dolomitic lime application on pasture productivity and quality. $\mathrm{EC}_{\mathrm{a}}$, soil apparent electrical conductivity; RFE, relative field elevation. Note: * Soil sampling in 2015 and pasture sampling in 2016 were carried out only in the original area of 2 ha.

\subsection{Soil Sampling, Interventions and Measurements}

The original experimental field ( 2 ha) was previously characterized by soil samples, collected in October 2015 [12], and pasture floristic composition, carried out in May 2016.

In November 2017, an extra area (2 ha) was added to the experimental field because manganese toxicity was identified and the effect of dolomitic lime and its interaction with the trees was intended to be tested. Dolomitic lime (42\% calcium oxide $(\mathrm{CaO})$ and $10 \%$ magnesium oxide $(\mathrm{MgO}) ; 2000 \mathrm{~kg} \cdot \mathrm{ha}^{-1}$ ) was applied to the surface of the original area of the experimental field (COR). In each area of 2 ha (amended area (COR) and unamended area (UCOR)), twelve grazing exclusion cages (dimensions of $0.50 \mathrm{~m} \times 0.50 \mathrm{~m}$ ) were installed as geo-referenced sampling points. Half of each of these sampling points was installed under the tree canopy (UTC) and the other half outside the tree canopy (OTC; Figure 4).

In October 2018, soil samples in these 24 geo-referenced points were collected using a gouge auger and a hammer, in a depth range of $0-0.30 \mathrm{~m}$. This soil was characterized in terms of $\mathrm{pH}$, organic matter $(\mathrm{OM})$, total nitrogen $\left(\mathrm{N}_{\text {total }}\right)$, phosphorus $(\mathrm{P})$, potassium $(\mathrm{K})$, magnesium $(\mathrm{Mg})$, manganese $(\mathrm{Mn})$, and exchange basis (calcium $\left(\mathrm{Ca}^{2+}\right)$, magnesium $\left(\mathrm{Mg}^{2+}\right)$, and potassium $\left(\mathrm{K}^{+}\right)$).

Soil samples were kept in plastic bags, air-dried, and sieved. The fine components $(<2 \mathrm{~mm})$ were analyzed using the following methods [13]: (i) $\mathrm{pH}$ in 1:2.5 (soil:water) suspension, using the potenciometric method; (ii) organic matter was measured by combustion and $\mathrm{CO}_{2}$ measurement, using an infrared detection cell; (iii) $\mathrm{N}_{\text {total }}$ with the Kjeldahl method; (iv) $\mathrm{P}$ and $\mathrm{K}$ were extracted by the Egner-Riehm method, $\mathrm{P}$ was measured using colorimetric method, and $\mathrm{K}$ content was measured with 
a flame photometer; (v) Mg and Mn were measured using atomic absorption spectrometry; and (vi) exchange basis were extracted with ammonium acetate.

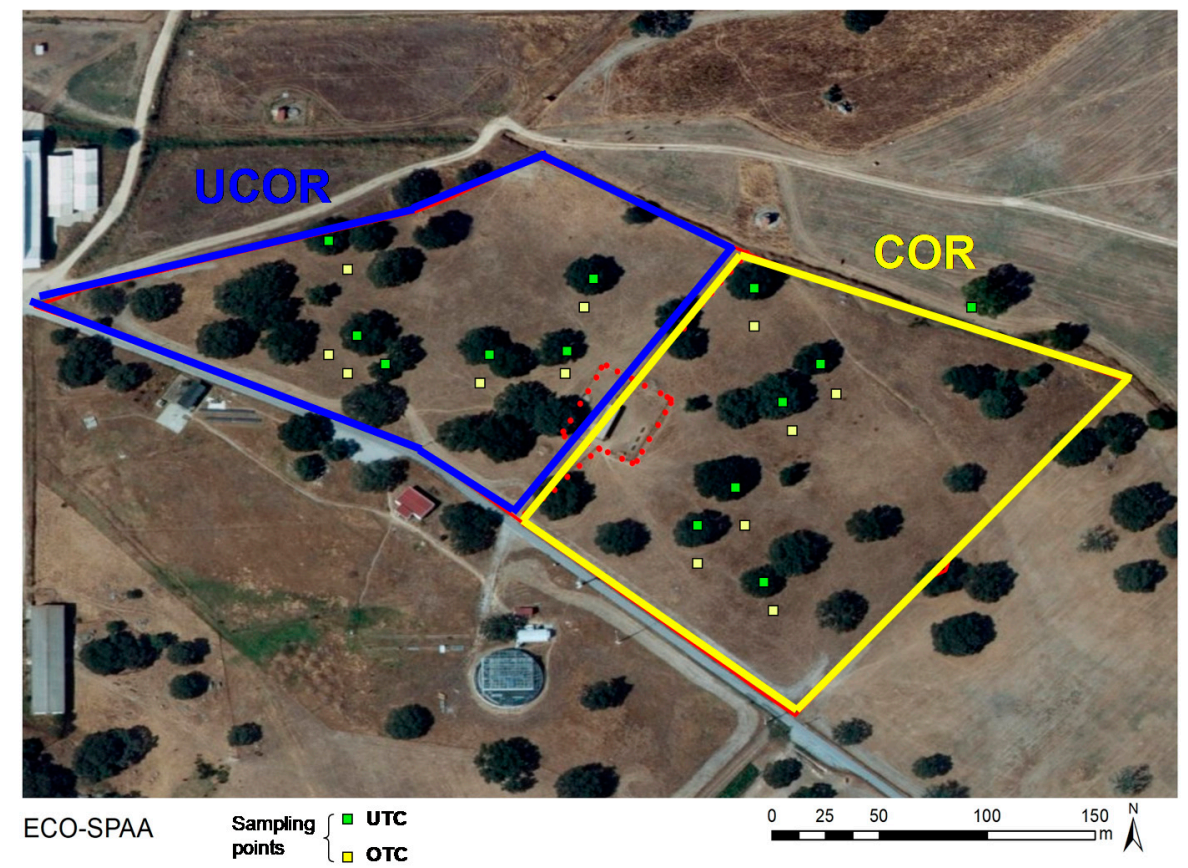

Figure 4. Experimental field: location of 24 sampling points (12 in the amended area (COR) and 12 in the unamended area (UCOR)). Half of sampling points were installed under tree canopy (UTC) and half outside tree canopy (OTC).

In November 2018, topographic and apparent soil electrical conductivity $\left(\mathrm{EC}_{\mathrm{a}}\right)$ surveys were completed. Topographic survey of the area was carried out using an all-terrain vehicle equipped with a real-time kinematics (RTK) GPS instrument (Trimble RTK/PP-4700 GPS, Trimble Navigation Limited, Sunnyvale, CA 94085, USA). The relative field elevation (RFE) map was created using the linear interpolation TIN tool from ArcGIS 9.3 and converted to a grid surface with a 1-m grid resolution. To measure the $\mathrm{EC}_{\mathrm{a}}$ in the experimental field, the Veris 2000 XA contact-type sensor (Veris Technologies, Salina, KS, USA), equipped with a global positioning system (GPS) antenna, was used.

In December 2018, ammonium phosphate (18\% of N and $\left.46 \% \mathrm{P} ; 100 \mathrm{~kg} \cdot \mathrm{ha}^{-1}\right)$ was applied to the surface throughout the experimental area.

In December 2018 and March and June 2019, cone index (CI, in kPa) measurements were carried out in the 24 sampling points with a cone penetrometer electronic FieldScout SC 900 (Spectrum Technologies, Aurora, IL, USA). In this study, the CI values between 0 and $0.20 \mathrm{~m}$, as the average of three measurements dates, were used. On the same dates, soil samples for determining the soil moisture content (SMC) in the top $0-0.20 \mathrm{~m}$ soil layer were taken at all sampling points using a gouge auger and a hammer. These soil samples were transported to the lab in metallic boxes, weighed, and then dried at $105^{\circ} \mathrm{C}$ for $24 \mathrm{~h}$. Once cooled, they were weighed again to establish SMC. The volumetric SMC was then obtained through multiplying the values by the bulk density.

\subsection{Pasture Sample Collection and Analysis}

During the pasture flowering period (May 2016), a floristic inventory of species present in each of the sampling points was carried out. In each sampling area $\left(0.25 \mathrm{~m}^{2}\right)$, the percentage of coverage by each species was recorded.

In the vegetative cycle of 2018/2019, at the end of autumn (December) 2018, of winter (March), and of spring (June) 2019, pasture productivity and quality parameters were monitored at 24 sampling points. Inside each sampling point, pasture was harvested with a portable electric grass shears at 
$1 \mathrm{~cm}$ above ground level and stored in marked plastic bags. The collected pasture samples were then subjected to the laboratory analysis: (i) weighing (to obtain fresh mass or green matter (GM) in $\left.\mathrm{kg} \cdot \mathrm{ha} \mathrm{a}^{-1}\right)$; (ii) dehydrated $\left(72 \mathrm{~h}\right.$ at $65^{\circ} \mathrm{C}$ ); (iii) weighed again (to obtain pasture moisture content (PMC) in percent and dry matter (DM) in $\mathrm{kg} \cdot \mathrm{ha}^{-1}$ ); and (iv) the dehydrated samples were subjected to standard analysis of wet chemistry according to the Association of Official Analytical Chemists [14] to determine key components of pasture quality, $\mathrm{CP}$ and fiber (NDF), both expressed as a percentage of DM. In the "Discussion", CP is expressed graphically in $\mathrm{kg} \cdot \mathrm{ha}^{-1}$, calculated from Equation (1). The "Discussion" also presents a pasture quality index (PQI), calculated according to Equation (2).

$$
\mathrm{CP}\left(\mathrm{kg} \cdot \mathrm{ha}^{-1}\right)=\frac{\mathrm{CP}(\%) \times \mathrm{DM}\left(\mathrm{kg} \cdot \mathrm{ha}^{-1}\right)}{100}
$$

where $\mathrm{CP}$ is crude protein $\left(\mathrm{kg} \cdot \mathrm{ha}^{-1}\right.$ and $\%$, respectively) and DMis dry matter $\left(\mathrm{kg} \cdot \mathrm{ha}^{-1}\right)$;

$$
\mathrm{PQI}=\frac{\mathrm{CP} \times \mathrm{PMC}}{\mathrm{NDF}}
$$

where $\mathrm{PQI}$ is the pasture quality index (\%), $\mathrm{CP}$ is the crude protein (\%), $\mathrm{PMC}$ is the pasture moisture content $(\%)$, and NDF is the neutral detergent fiber (\%).

\subsection{Statistical Analysis}

Descriptive statistical analysis (mean, standard variation, and range) was performed for soil and pasture parameters. Then, ANOVA of the data was carried out considering a two factor experiment (soil correction, COR vs. UCOR, and influence of tree canopy, UTC vs. OTC), using "MSTAT-C" software with a $95 \%$ significance level $(p<0.05)$. Because soil correction was not repeated in space, the interactions between fields and replicas were used to generate the error to compare the two fields. The "Fisher" ("Fisher's least significant difference, LSD") test was applied whenever the ANOVA results presented significant differences between factors.

\section{Results}

\subsection{Variability Pattern of the Soil Parameters}

The starting point for this study was the evaluation of the soil of the experimental field carried out in October 2015, which showed that this is an acid soil (mean $\mathrm{pH}_{\mathrm{H} 2 \mathrm{O}}=5.4 \pm 0.3$ ) [12].

In addition to acidity, the soils of this region of Portugal have some other characteristics that affect crop productivity. Figure 5a shows the relative field elevation (RFE) map of the experimental field, with undulated relief typical of the southern region of Portugal, and an 8-m difference (220-228 m) between the highest and the lowest altimetry. Altimetric information is important inasmuch as it affects soil drainage and fertility [15], the major drivers of the productivity in dryland pastures [16]. Figure $5 b$ shows the soil apparent electrical conductivity $\left(\mathrm{EC}_{\mathrm{a}}\right)$ map, with a mean value of $1.7 \pm 0.2 \mathrm{mS} \cdot \mathrm{m}^{-1}$, which reflects the sandy loam texture (sand $=80.6 \pm 2.3 \%$; silt $=10.1 \pm 1.7 \%$; and clay $=9.3 \pm 1.4 \%$ ) and other structural limitations of these soils [17]. The spatial information that results from the combination of these surveys (altimetry and $\mathrm{EC}_{\mathrm{a}}$ ) has a great potential for principal component analysis (PCA) in order to identify and define soil management zones) and select the factors that determine crop yield $[15,18,19]$.

In November 2018, a year after soil amendment, the superficial soil layer was evaluated. Tables 1 and 2 show, respectively, the descriptive and inferential statistics of the soil parameters at the experimental field on this date. The main aspects to be highlighted are: (i) The spatial variability of all soil parameters, except for $\mathrm{pH}_{\mathrm{H} 2 \mathrm{O}}$ is high; the high $\mathrm{CV}(30-70 \%)$ is a result of the simultaneous effect of trees and animal grazing [12]. (ii) The soil amendment was significant in terms of $\mathrm{pH}_{\mathrm{H} 2 \mathrm{O}}$ (5.58 \pm 0.15 in COR areas and $5.30 \pm 0.19$ in UCOR areas; $\mathrm{P}=0.0193)$ but not in terms of macronutrients availability; only the UCOR areas showed significantly more $\mathrm{Mn}\left(66.8 \pm 31.4 \mathrm{mg} \cdot \mathrm{kg}^{-1}\right.$ in UCOR areas 
and $33.6 \pm 16.1 \mathrm{mg} \cdot \mathrm{kg}^{-1}$ in COR areas; $\mathrm{P}=0.0000$ ); as the dolomitic lime is rich in calcium and $\mathrm{Mg}$, the $\mathrm{Mg} / \mathrm{Mn}$ ratio increased from 1.1 in UCOR areas to 2.5 in COR areas (reaching 4.2 UTC), which is a relevant aspect due to the toxicity problems of $\mathrm{Mn}$ in acid Cambisols, recognized as the major limitation for pasture and forage production in the Montado ecosystem [2]. (iii) Tree canopy significantly improved all the evaluated parameters ( $\mathrm{pH}, \mathrm{OM}, \mathrm{N}_{\text {total }}, \mathrm{P}$, and $\mathrm{K}$ ), except for $\mathrm{Mg}, \mathrm{Mn}$, and exchange basis. Mg and exchange basis showed no significant differences, while Mn showed significantly higher values OTC. This positive effect of trees on soil fertility has also been demonstrated by several other studies $[6,20]$.
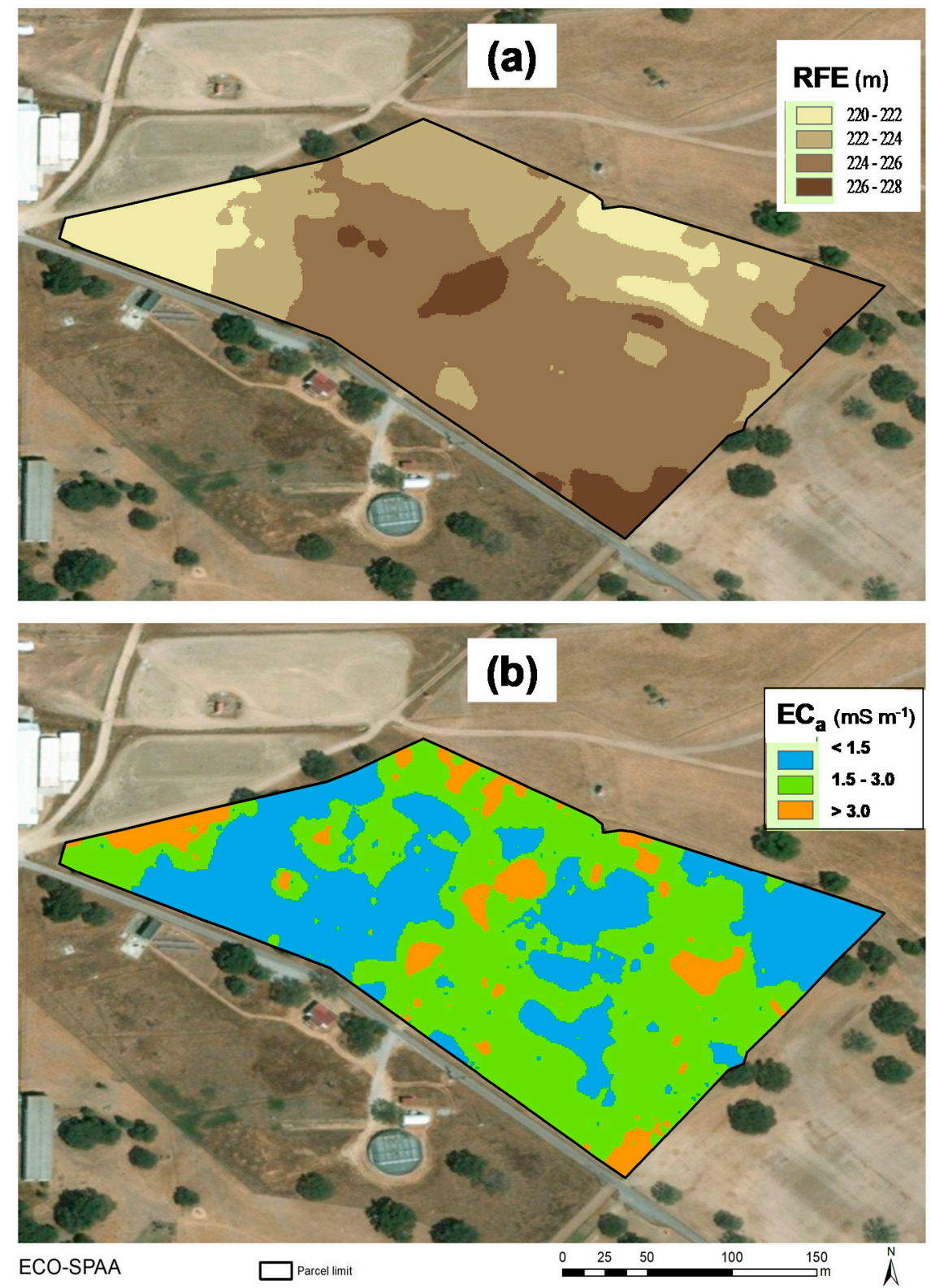

Figure 5. Maps of the experimental field's relative field elevation (RFE) (a) and soil apparent electrical conductivity $\left(\mathrm{EC}_{\mathrm{a}}\right)(\mathbf{b})$. 
Table 1. Descriptive statistics of soil parameters of the experimental field in November 2018 (sampling depth: 0-0.30 m) at all areas (Global), corrected areas (COR), uncorrected areas (UCOR), and under and outside tree canopy (UTC and OTC, respectively) areas.

\begin{tabular}{|c|c|c|c|c|c|c|c|c|c|c|}
\hline \multirow{2}{*}{$\begin{array}{l}\text { Soil Parameters } \\
\text { (n) }\end{array}$} & \multicolumn{2}{|c|}{ GLOBAL (24) } & \multicolumn{2}{|c|}{ COR (12) } & \multicolumn{2}{|c|}{ UCOR (12) } & \multicolumn{2}{|c|}{ UTC (12) } & \multicolumn{2}{|c|}{ OTC (12) } \\
\hline & Mean \pm SD & Range & Mean \pm SD & Range & Mean \pm SD & Range & Mean \pm SD & Range & Mean \pm SD & Range \\
\hline $\mathrm{pH}_{\mathrm{H} 2 \mathrm{O}}$ & $5.44 \pm 0.22$ & $5.50-5.90$ & $5.58 \pm 0.15$ & $5.40-5.90$ & $5.30 \pm 0.19$ & $5.00-5.60$ & $5.53 \pm 0.20$ & $5.20-5.90$ & $5.33 \pm 0.19$ & $5.00-5.60$ \\
\hline $\mathrm{OM}(\%)$ & $1.56 \pm 0.59$ & $0.90-3.00$ & $1.66 \pm 0.66$ & $1.00-3.00$ & $1.47 \pm 0.52$ & $0.90-2.37$ & $2.03 \pm 0.46$ & $1.40-3.00$ & $1.10 \pm 0.18$ & $0.90-1.50$ \\
\hline $\mathrm{N}_{\text {total }}(\%)$ & $0.10 \pm 0.03$ & $0.05-0.19$ & $0.09 \pm 0.03$ & $0.06-0.15$ & $0.10 \pm 0.04$ & $0.05-0.19$ & $0.12 \pm 0.03$ & $0.08-0.19$ & $0.07 \pm 0.01$ & $0.05-0.10$ \\
\hline $\mathrm{P}\left(\mathrm{mg} \cdot \mathrm{kg}^{-1}\right)$ & $54.2 \pm 31.8$ & 8-107 & $55.4 \pm 30.8$ & 20-107 & $53.0 \pm 34.1$ & 8-101 & $63.6 \pm 32.3$ & 8-107 & $44.8 \pm 29.6$ & $14-98$ \\
\hline $\mathrm{K}\left(\mathrm{mg} \cdot \mathrm{kg}^{-1}\right)$ & $155.0 \pm 57.8$ & $56-310$ & $164.8 \pm 64.0$ & $80-310$ & $145.2 \pm 51.6$ & $56-204$ & $200.3 \pm 38.2$ & $162-310$ & $109.7 \pm 32.2$ & $56-168$ \\
\hline $\mathrm{Mg}\left(\mathrm{mg} \cdot \mathrm{kg}^{-1}\right)$ & $78.1 \pm 33.0$ & $35-160$ & $82.9 \pm 32.1$ & $50-160$ & $73.3 \pm 34.6$ & 35-155 & $84.2 \pm 21.2$ & $35-160$ & $72.1 \pm 41.8$ & $50-120$ \\
\hline $\mathrm{Mn}\left(\mathrm{mg} \cdot \mathrm{kg}^{-1}\right)$ & $50.2 \pm 29.7$ & 15-135 & $33.6 \pm 16.1$ & $15-67$ & $66.8 \pm 31.4$ & $16-135$ & $38.4 \pm 23.4$ & $15-90$ & $62.1 \pm 31.5$ & $25-135$ \\
\hline $\mathrm{Ca}^{2+}\left(\mathrm{mmol} \cdot \mathrm{dm}^{-3}\right)$ & $2.2 \pm 0.8$ & $1.1-3.6$ & $2.4 \pm 0.8$ & $1.1-3.6$ & $2.0 \pm 0.6$ & $1.1-3.1$ & $2.6 \pm 0.7$ & $1.6-3.6$ & $1.7 \pm 0.5$ & $1.1-2.7$ \\
\hline $\mathrm{Mg}^{2+}\left(\mathrm{mmol} \cdot \mathrm{dm}^{-3}\right)$ & $0.6 \pm 0.3$ & $0.2-1.4$ & $0.7 \pm 0.3$ & $0.3-1.4$ & $0.5 \pm 0.2$ & $0.2-1.2$ & $0.6 \pm 0.1$ & $0.5-0.9$ & $0.6 \pm 0.4$ & $0.2-1.4$ \\
\hline $\mathrm{K}^{+}\left(\mathrm{mmol} \cdot \mathrm{dm}^{-3}\right)$ & $0.9 \pm 0.4$ & $0.3-1.5$ & $0.9 \pm 0.5$ & $0.3-1.5$ & $0.9 \pm 0.3$ & $0.4-1.5$ & $1.1 \pm 0.3$ & $0.7-1.5$ & $0.7 \pm 0.4$ & $0.3-1.5$ \\
\hline
\end{tabular}

exchange basis.

Table 2. Mean of soil parameters and probability (Prob.) of significant differences between corrected (COR) and uncorrected (UCOR) and between under tree canopy (UTC) and outside tree canopy (OTC) areas of the experimental field in November 2018. Different lowercase letters in the factorial analysis indicate significant differences to the mean of pasture parameters for the "Fisher's" test (Prob. <0.05).

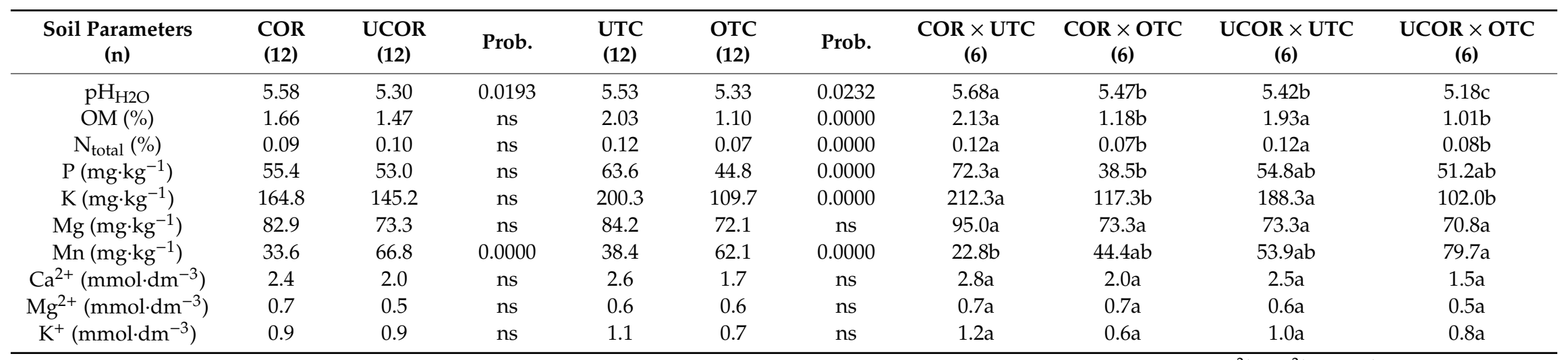

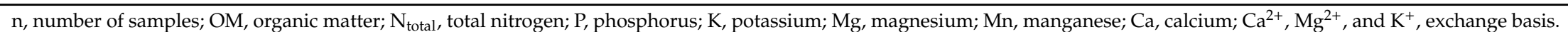




\subsection{Variability Pattern of the Pasture Parameters}

The objective of this work was to evaluate the simultaneous effect of the application of dolomitic lime and the tree canopy on the productivity and quality of a permanent biodiverse pasture in an acid soil.

Figure 6 shows the predominant botanical species of the biodiverse pasture of the studied field evaluated in spring 2016, UTC and OTC. These nine species represent approximately $80 \%$ of the total mean cover. Most of these species are annuals, with pronounced patchiness of vegetation communities and marked seasonality of plant cycles, which germinate according to yearly environmental conditions (e.g., temperature and rainfall); consequently, the species composition of grassland in Montado can have a high inter-annual variability [9]. The most representative species are the Erodium moschatum (UTC) and the Chamamelum mixtum (OTC). This spatial variability of the botanical composition is caused by changes in the microclimate (mainly shade tolerance), soil properties, and livestock grazing [9].

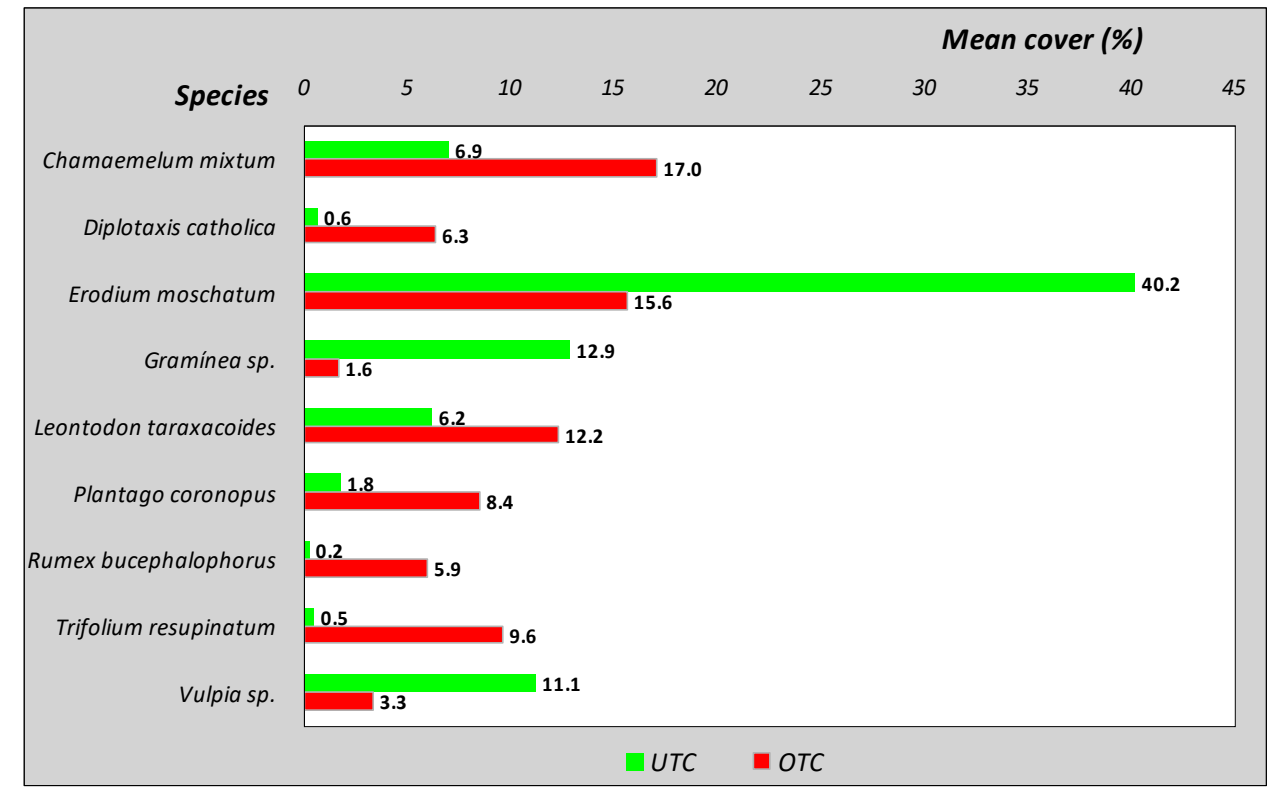

Figure 6. Predominant botanical species (mean cover, \%) present in the pasture of the studied field in spring 2016, under tree canopy (UTC) and outside tree canopy (OTC).

Tables 3 and 4 show, respectively, the descriptive and inferential statistics of the pasture parameters at the experimental field on three dates: end of autumn (December 2018), end of winter (March 2019), and end of spring (June 2019). The main aspects to be highlighted are: (i) Similar to what was observed in terms of the soil parameters, there is a high spatial variability in pasture productivity (GM and $\mathrm{DM} ; \mathrm{CV}=40-70 \%)$ and $\mathrm{CP}(\mathrm{CV}=30-40 \%)$ and a low to moderate variability of PMC and NDF $(\mathrm{CV}=5-40 \%)$. (ii) The soil amendment showed a positive effect on pasture productivity (GM and $\mathrm{DM}$ ), which was significant only in the end of the winter. (iii) Tree canopy effect is positive on CP, and significant in the autumn and in the spring, and is negative on pasture productivity (GM and DM), and significant in the winter and spring. This effect of tree canopy on pasture productivity and quality has also been demonstrated by several other studies $[6,7,12]$. 
Table 3. Descriptive statistics of pasture parameters of the experimental field in autumn (December 2018), winter (March 2019), and spring (June 2019) at all area (Global), corrected areas (COR), uncorrected areas (UCOR), and under and outside tree canopy (UTC and OTC, respectively) areas.

\begin{tabular}{|c|c|c|c|c|c|c|c|c|c|c|}
\hline \multirow{2}{*}{$\begin{array}{l}\text { Pasture Parameters } \\
\text { (n) }\end{array}$} & \multicolumn{2}{|c|}{ GLOBAL (24) } & \multicolumn{2}{|c|}{ COR (12) } & \multicolumn{2}{|c|}{ UCOR (12) } & \multicolumn{2}{|c|}{ UTC (12) } & \multicolumn{2}{|c|}{ OTC (12) } \\
\hline & Mean \pm SD & Range & Mean \pm SD & Range & Mean \pm SD & Range & Mean \pm SD & Range & Mean \pm SD & Range \\
\hline \multicolumn{11}{|l|}{ GM (kg.ha $\left.{ }^{-1}\right)$} \\
\hline Autumn & $7328 \pm 2933$ & $900-15,990$ & $7873 \pm 3412$ & $2900-15,990$ & $6783 \pm 2388$ & $3500-11,000$ & $6766 \pm 3524$ & $2900-15,990$ & $7891 \pm 2909$ & $5400-12,000$ \\
\hline Winter & $12,475 \pm 8484$ & $1800-34,900$ & $16,258 \pm 9751$ & $6500-34,900$ & $8692 \pm 4917$ & $1800-15,200$ & $9150 \pm 8076$ & $1800-30,800$ & $15,800 \pm 7820$ & $7000-34,900$ \\
\hline Spring & $4779 \pm 2655$ & 900-8400 & $4908 \pm 2611$ & $1600-8400$ & $4650 \pm 2808$ & 900-8300 & $2708 \pm 1392$ & $900-5300$ & $6850 \pm 1856$ & $2100-8400$ \\
\hline \multicolumn{11}{|l|}{ DM (kg.ha $\left.a^{-1}\right)$} \\
\hline Autumn & $1038 \pm 431$ & $400-2500$ & $1117 \pm 567$ & $400-2500$ & $958 \pm 231$ & $600-1400$ & $1033 \pm 555$ & $400-2500$ & $1042 \pm 284$ & $700-1700$ \\
\hline Winter & $1833 \pm 848$ & $600-4100$ & $2317 \pm 928$ & $1100-4100$ & $1350 \pm 363$ & $600-1800$ & $1592 \pm 814$ & $600-3500$ & $2075 \pm 844$ & $1200-4100$ \\
\hline Spring & $3067 \pm 1807$ & $500-6900$ & $3025 \pm 1839$ & $900-6900$ & $3108 \pm 1855$ & $500-5600$ & $1667 \pm 947$ & $500-3400$ & $4467 \pm 1286$ & $1700-6900$ \\
\hline \multicolumn{11}{|l|}{ PMC (\%) } \\
\hline Autumn & $85.5 \pm 2.9$ & $77.8-90.8$ & $85.9 \pm 2.5$ & $81.1-90.8$ & $85.1 \pm 3.3$ & $77.8-89.1$ & $84.5 \pm 2.8$ & $77.8-88.9$ & $86.5 \pm 2.6$ & $81.1-90.8$ \\
\hline Winter & $82.4 \pm 6.2$ & $66.7-88.7$ & $83.9 \pm 4.3$ & $76.9-88.6$ & $80.9 \pm 7.6$ & $66.7-88.7$ & $78.7 \pm 6.4$ & $66.7-88.6$ & $86.1 \pm 3.3$ & $77.1-88.7$ \\
\hline Spring & $35.9 \pm 13.5$ & $5.0-64.3$ & $39.1 \pm 13.1$ & $17.9-64.3$ & $32.8 \pm 13.7$ & $5.0-57.0$ & $38.6 \pm 14.6$ & $5.0-64.3$ & $33.2 \pm 12.3$ & $17.9-57.0$ \\
\hline \multicolumn{11}{|l|}{$\mathrm{CP}(\%)$} \\
\hline Autumn & $22.8 \pm 6.6$ & $13.4-47.3$ & $24.7 \pm 8.6$ & $13.4-47.3$ & $21.0 \pm 3.2$ & $16.9-29.7$ & $25.1 \pm 8.0$ & $17.7-47.3$ & $20.5 \pm 3.9$ & $13.4-25.8$ \\
\hline Winter & $19.4 \pm 5.4$ & $10.8-31.2$ & $19.6 \pm 6.2$ & $10.8-31.2$ & $19.1 \pm 4.8$ & $13.9-25.7$ & $20.3 \pm 6.1$ & $13.9-31.2$ & $18.4 \pm 4.7$ & $10.8-25.7$ \\
\hline Spring & $9.7 \pm 3.8$ & $5.1-21.4$ & $10.5 \pm 5.1$ & $5.1-21.4$ & $8.9 \pm 1.9$ & $6.0-13.0$ & $12.2 \pm 4.0$ & 8.8-21.4 & $7.2 \pm 1.3$ & $5.1-9.9$ \\
\hline \multicolumn{11}{|l|}{ NDF (\%) } \\
\hline Autumn & $49.5 \pm 8.3$ & $28.5-64.5$ & $48.5 \pm 9.7$ & $28.5-64.5$ & $50.4 \pm 6.9$ & 41.0-61.1 & $52.2 \pm 6.6$ & 41.0-61.1 & $46.7 \pm 9.2$ & $28.5-64.5$ \\
\hline Winter & $45.9 \pm 8.4$ & $34.2-62.1$ & $43.1 \pm 6.9$ & $34.2-55.3$ & $48.7 \pm 9.0$ & $39.5-62.1$ & $50.6 \pm 9.1$ & $34.2-62.1$ & $41.2 \pm 3.8$ & $34.8-49.4$ \\
\hline Spring & $64.6 \pm 4.1$ & $56.0-70.7$ & $63.6 \pm 5.0$ & $56.0-70.4$ & $65.6 \pm 2.8$ & 61.9-70.7 & $62.7 \pm 4.0$ & $56.0-68.4$ & $66.5 \pm 3.4$ & $61.4-70.7$ \\
\hline
\end{tabular}

n, number of samples; Prob., probability; GM, green matter; DM, dry matter; PMC, pasture moisture content; $\mathrm{CP}$, crude protein; NDF, neutral detergent fiber. 
Table 4. Mean of pasture parameters and probability (Prob.) of significant differences between corrected (COR) and uncorrected (UCOR) areas and between under tree canopy (UTC) and outside tree canopy (OTC) areas of the experimental field in autumn (December 2018), winter (March 2019), and spring (June 2019).

Different lowercase letters in the factorial analysis indicate significant differences to the mean of pasture parameters for the "Fisher's" test (Prob. $<0.05$ ).

\begin{tabular}{|c|c|c|c|c|c|c|c|c|c|c|}
\hline $\begin{array}{l}\text { Pasture Parameters } \\
\text { (n) }\end{array}$ & $\begin{array}{l}\text { COR } \\
(12)\end{array}$ & $\begin{array}{c}\text { UCOR } \\
\text { (12) }\end{array}$ & Prob. & $\begin{array}{l}\text { UTC } \\
\text { (12) }\end{array}$ & $\begin{array}{c}\text { OTC } \\
(12)\end{array}$ & Prob. & $\underset{(6)}{\mathrm{COR} \times \mathrm{UTC}}$ & $\begin{array}{c}\mathrm{COR} \times \mathrm{OTC} \\
(\mathbf{6})\end{array}$ & $\underset{(6)}{\mathrm{UCOR} \times \mathrm{UTC}}$ & $\begin{array}{c}\mathrm{UCOR} \times \mathrm{OTC} \\
(6)\end{array}$ \\
\hline \multicolumn{11}{|l|}{ GM (kg.ha $\left.{ }^{-1}\right)$} \\
\hline Autumn & 7873 & 6783 & ns & 6766 & 7891 & ns & $7948 a$ & $7798 a$ & $5583 a$ & $7983 a$ \\
\hline Winter & 16,258 & 8692 & 0.0486 & 9150 & 15,800 & 0.0205 & $13,700 \mathrm{a}$ & $18,817 \mathrm{a}$ & $4600 \mathrm{~b}$ & $12,783 a$ \\
\hline Spring & 4908 & 4650 & ns & 2708 & 6850 & 0.0001 & $3267 \mathrm{~b}$ & $6550 a$ & $2150 \mathrm{~b}$ & $7150 a$ \\
\hline \multicolumn{11}{|l|}{ DM (kg.ha $\left.{ }^{-1}\right)$} \\
\hline Autumn & 1117 & 958 & ns & 1033 & 1042 & ns & $1200 a$ & $1033 a$ & $867 a$ & $1050 \mathrm{a}$ \\
\hline Winter & 2317 & 1350 & 0.0198 & 1592 & 2075 & 0.0307 & $2083 \mathrm{ab}$ & $2550 a$ & $1100 \mathrm{c}$ & $1600 \mathrm{bc}$ \\
\hline Spring & 3025 & 3108 & ns & 1667 & 4467 & 0.0002 & $1833 b$ & $4217 a$ & $1500 \mathrm{~b}$ & $4717 a$ \\
\hline \multicolumn{11}{|l|}{ PMC (\%) } \\
\hline$\overline{\text { Autumn }}$ & 85.9 & 85.1 & ns & 84.5 & 86.6 & 0.0700 & $85.3 a$ & $86.6 \mathrm{a}$ & $83.7 \mathrm{a}$ & $86.5 a$ \\
\hline Winter & 83.9 & 80.9 & ns & 78.7 & 86.1 & 0.0017 & $82.7 \mathrm{a}$ & $85.1 \mathrm{a}$ & $74.7 \mathrm{~b}$ & $87.1 \mathrm{a}$ \\
\hline Spring & 39.1 & 32.8 & ns & 38.6 & 33.3 & ns & $44.6 \mathrm{a}$ & $33.5 a$ & $32.6 a$ & $32.9 a$ \\
\hline \multicolumn{11}{|l|}{ CP (\%) } \\
\hline$\overline{\text { Autumn }}$ & 24.7 & 21.0 & ns & 25.1 & 20.5 & 0.0708 & $28.5 a$ & $20.9 b$ & $21.8 \mathrm{ab}$ & $20.2 b$ \\
\hline Winter & 19.6 & 19.1 & ns & 20.3 & 18.4 & ns & $23.5 a$ & $15.7 \mathrm{~b}$ & $17.1 \mathrm{~b}$ & $21.2 \mathrm{ab}$ \\
\hline Spring & 10.5 & 8.9 & ns & 12.2 & 7.2 & 0.0004 & $14.1 \mathrm{a}$ & $6.8 \mathrm{c}$ & $10.2 b$ & $7.6 b c$ \\
\hline \multicolumn{11}{|l|}{ NDF (\%) } \\
\hline$\overline{\text { Autumn }}$ & 48.5 & 50.4 & ns & 52.2 & 46.7 & ns & $50.7 a$ & $46.3 a$ & $53.8 \mathrm{a}$ & 47.1a \\
\hline Winter & 43.1 & 48.8 & 0.0424 & 50.7 & 41.2 & 0.0014 & $44.7 \mathrm{~b}$ & $41.5 \mathrm{~b}$ & $56.7 \mathrm{a}$ & $40.8 \mathrm{~b}$ \\
\hline Spring & 63.6 & 65.6 & ns & 62.8 & 66.5 & 0.0457 & $60.6 \mathrm{~b}$ & $66.7 a$ & $64.9 \mathrm{ab}$ & $66.3 a$ \\
\hline
\end{tabular}

$\mathrm{n}$, number of samples; GM, green matter; DM, dry matter; PMC, pasture moisture content; $\mathrm{CP}$, crude protein; NDF, neutral detergent fiber. 


\section{Discussion}

\subsection{Variability Pattern of the Soil Parameters}

The 21st century began with two major challenges for agriculture: (i) to increase productivity; and (ii) to attain greater sustainability of the productive systems. One of the great challenges in modern agriculture is, therefore, creating systems that combine lower levels of input with higher food production and minimum environmental impacts [21]. The projections indicate a $30 \%$ increase in the world population between 2015 and 2050 (from 7.3 to 9.5 billion), thus the corresponding increase in food demand requires an increase in agricultural production of $~ 70 \%$ [22]. On the other hand, soil is a non-renewable resource on human time scales with its vulnerability to degradation depending on complex interactions among processes, factors, and causes occurring at a range of spatial and temporal scales [22]. It is in this context that it is important to evaluate the possibility of intensifying extensive livestock production by increasing pasture productivity in Mediterranean Montado ecosystem, and simultaneously contributing to soil preservation. Furthermore, grasslands are among the most widespread vegetation types worldwide, covering between $14 \%$ and $26 \%$ of the Earth's surface, and they play an important role in the carbon cycle and in mitigating climate changes [23].

The sustainability of these large cork and holm oak areas is, nevertheless, currently threatened by forecasted climate changes and inappropriate management practices [24]. In the Southern region of Portugal, it is common practice to apply phosphate fertilizers at intervals of two or three years with the aim of improving the fertility of these poor soils [4]. However, the impact of this improvement on pasture productivity is conditioned by an objective limitation: soil acidity. The yield of crops in these Cambisols developed on granitic formations is generally poor as a consequence of the Mn toxicity [2]. In this study, the surface application of dolomitic lime (2000 kg.ha $\left.{ }^{-1}\right)$ in November 2017 had a direct impact on soil $\mathrm{pH}_{\mathrm{H} 2 \mathrm{O}}$ (from $5.4 \pm 0.3$ in 2015 to $5.6 \pm 0.2$ in 2018), with a clearer effect $\mathrm{UTC}$ areas (mean $\mathrm{pH}_{\mathrm{H} 2 \mathrm{O}}=5.7$ ) than in OTC areas (mean $\mathrm{pH}_{\mathrm{H} 2 \mathrm{O}}=5.5$ ) (Figure 7). These results show that surface lime application was an efficient practice for increasing $\mathrm{pH}$ and reducing the exchangeable acidity [25]. However, the application of amendments does not increase much the soil $\mathrm{pH}_{\mathrm{H} 2 \mathrm{O}}$ immediately, but rather gradually over time [26]. This is in line with other studies [27], which also reflects the way in which lime was applied in the field (surface application, not incorporated into the soil through mobilization). The application also had a positive and significant effect on the $\mathrm{Mg} / \mathrm{Mn}$ ratio, increasing from close to 1 in UCOR areas to more than 4 in COR $\times$ UTC areas (Figure 7). This aspect is particularly important since Mn toxicity has long been recognized as an important factor limiting plant growth on acid soils [2]. The result of this toxicity is a reduction in the soil productive potential, conditioning, in the case of biodiverse pastures, its floristic diversity, which makes them less interesting from an agronomic and nutritional point of view [2]. According to Halim et al. [26], soil amendment is suitable for two primary categories of problems, including reducing contaminant bioavailability/phytoavailability and improving poor soil health and ecosystem function, since it improves cation exchange capacity (CEC), increases water holding capacity and re-establishes microbial communities as well as soil structure by alleviating compaction.

Appropriate indicators of soil chemical quality include $\mathrm{pH}_{\mathrm{H} 2 \mathrm{O}}, \mathrm{CEC}$, nutrient availability, favorable elemental balance, and absence of any toxicity or deficiency [22]. The improvement of soil chemical attributes with the superficial application of lime observed in this study follows the trend observed in other works [28]. In the context of the mixed Montado ecosystem, the evaluation of the effect of soil $\mathrm{pH}_{\mathrm{H} 2 \mathrm{O}}$ correction cannot be dissociated from the tree canopy effect on the soil. Areas corrected and under tree canopies $(\mathrm{COR} \times \mathrm{UTC})$ showed significantly higher levels of OM (2.13\% in COR $\times$ UTC areas vs. $1.01 \%$ in UCOR $\times$ OTC areas), nitrogen $(0.12 \%$ in COR $\times$ UTC areas vs. $0.08 \%$ in UCOR $\times$ OTC areas), phosphorus $\left(72.3 \mathrm{mg} \cdot \mathrm{kg}^{-1}\right.$ in COR $\times$ UTC areas vs. $51.2 \mathrm{mg} \cdot \mathrm{kg}^{-1}$ in UCOR $\times$ OTC areas), and potassium $\left(212.3 \mathrm{mg} \cdot \mathrm{kg}^{-1}\right.$ in COR $\times$ UTC areas vs. $102.0 \mathrm{mg} \cdot \mathrm{kg}^{-1}$ in $\mathrm{UCOR} \times \mathrm{OTC}$ areas). The positive effect of tree canopy on soil fertility has been documented in several studies [6,12,29]. Improving soil quality (i.e., increasing soil organic carbon (SOC) pool, improving soil 
structure, and enhancing soil fertility) can reduce risks of soil degradation (physical, chemical, biological, and ecological) while improving the environment [22]. Developing strategies to ensure that SOC pool (key indicator of soil quality and an important driver of agricultural sustainability) stays above the threshold or critical level of 1.0-1.5\%, especially in the European semi-arid Mediterranean regions, is essential for reducing soil degradation risks and reversing degradation trends [22].

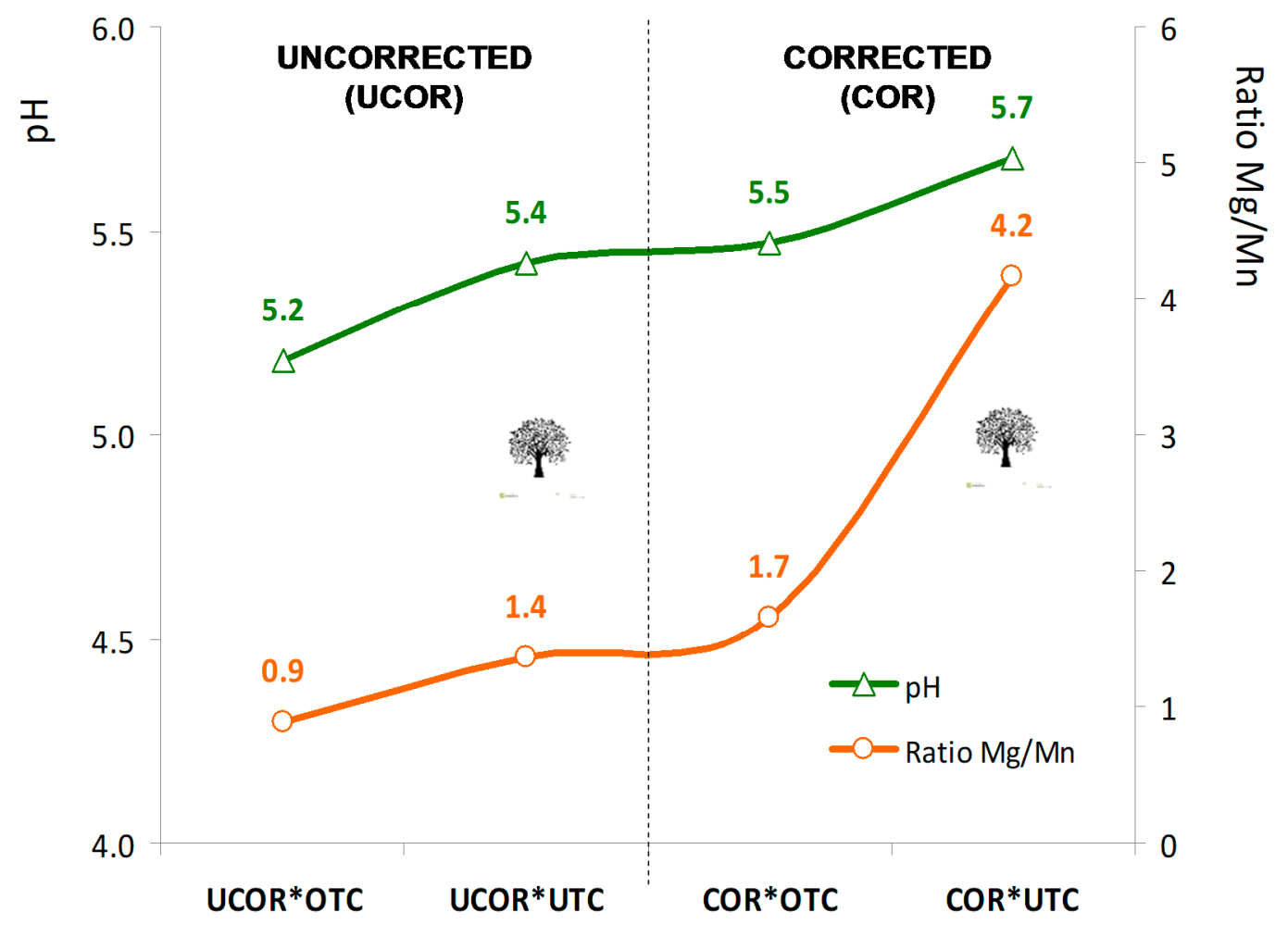

Figure 7. Soil $\mathrm{pH}_{\mathrm{H} 2 \mathrm{O}}$ and $\mathrm{Mg} / \mathrm{Mn}$ ratio of the experimental field.

In terms of topsoil compaction (0-0.20 m surface layer, where grass roots normally develop [4]), Figure 8a shows a trend towards greater soil penetration resistance in UCOR areas relatively to COR areas in the soil layer between 0.10 and $0.15 \mathrm{~m}$, which will justify in the future a more detailed study to identify possible causes of this behavior and its impact on pasture development. Figure $8 \mathrm{~b}$ shows, on the other hand, very similar soil penetration resistance patterns in UTC and OTC areas, which do not indicate a possible greater compaction that would result from the animals choosing the tree shade as preferred resting areas. This aspect might be explained by the fact that the animals use these places especially in the summer season, looking for shade, when the soil is relatively dry and, therefore, less susceptible to compaction. On the other hand, increased soil compaction due to the effect of tree roots is expected at greater depths [9].

\subsection{Variability Pattern of the Pasture Parameters}

In the previous section, the contribution of lime application to improve soil fertility and the sustainability of the Montado ecosystem is presented, highlighting the interactions that result from the presence of trees and grazing animals. In this section, the impact of these interventions and interactions on productivity and quality of pasture is evaluated, as final indicators of their success and the possibility of intensifying livestock production, necessary to respond to the growing global food requirements.

Grassland productivity and quality depends on the interaction between soil, plant, animal, and climate factors, where the correction of soil reaction and fertility [28] plays a crucial role. In extreme cases, of very acidic soils, soil amendments are elements added to the soil to improve its capacity to 
support plant life [26]. In this study, the topsoil shows medium acidity [4] and, therefore, what is intended is to evaluate the possibility of optimizing pasture productivity and quality.
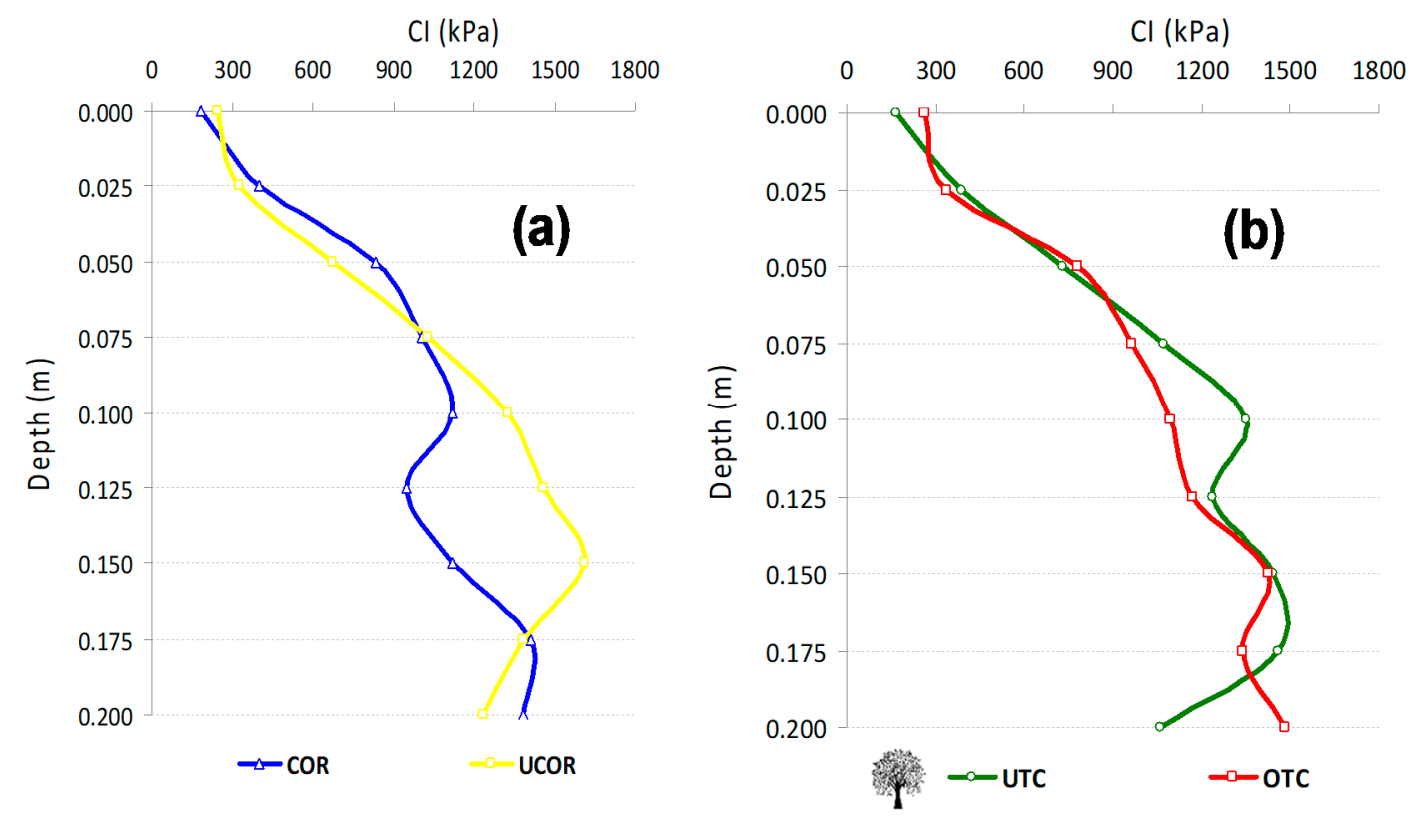

Figure 8. Average soil cone index (CI) in the 0-0.20 m layer: (a) comparison between corrected (COR) and uncorrected (UCOR) areas; and (b) comparison between under tree canopy (UTC) and outside tree canopy (OTC) areas.

In all seasons (autumn, winter, and spring), soil amendment showed a tendency to improve pasture productivity (GM and DM) and quality (higher CP and PMC and lower NDF) (Tables 3 and 4). On the other hand, tree canopy showed a tendency to improve pastures $\mathrm{CP}$, presenting an irregular season-dependent behavior with regard to PMC and NDF and a tendency for a negative effect on pasture productivity (GM and DM). This effect of tree canopy on pasture productivity and quality has also been demonstrated by several other studies [6,7,12]. Dryland pasture development is dependent on the agricultural year in terms of rainfall distribution [4]. In this case, the effects of a relatively normal autumn, with a peak precipitation of about $100 \mathrm{~mm}$ in November 2018, a dry winter (accumulated rainfall of about $75 \mathrm{~mm}$ ), and a late spring (May and June) without precipitation (Figure 2), were reflected in the SMC of the surface layer (0-0.20 m; Figure 9), with average values of $14.7 \%, 11.3 \%$, and $3.5 \%$, respectively, in the end of autumn, winter, and spring. This distribution of precipitation tends to favor the autumnal growth of the pasture, but compromises the rest of the pasture cycle and, consequently, the spring peak of production [4]. Indeed, the dry winter imposed lower SMC levels than its equivalent in autumn, which was reflected in the positive and significant effect of lime application on winter pasture productivity (Table 4). According to Efe Serrano [4], the distribution of precipitation between March and June is one of the factors that determine the annual pasture production, mainly due to its influence on the extension of the vegetative cycle. Competition for water is usually the main limiting factor for pasture growth, particularly in regions subjected to summer droughts with high temperatures and incident radiation. Soil water deficit results in lower forage DM yields primarily by limiting leaf area development and reducing photosynthesis due to stomatal closure [6].

The abrupt drop in moisture in the topsoil from March (end of winter) to June (end of spring) resulted in a strong decrease in the quality of pasture (with very significant breaks in PMC and CP and a substantial increase in NDF, all expressed in percent of DM), reflected in the abrupt PQI break in the whole area of the experimental field (Figure 10). 


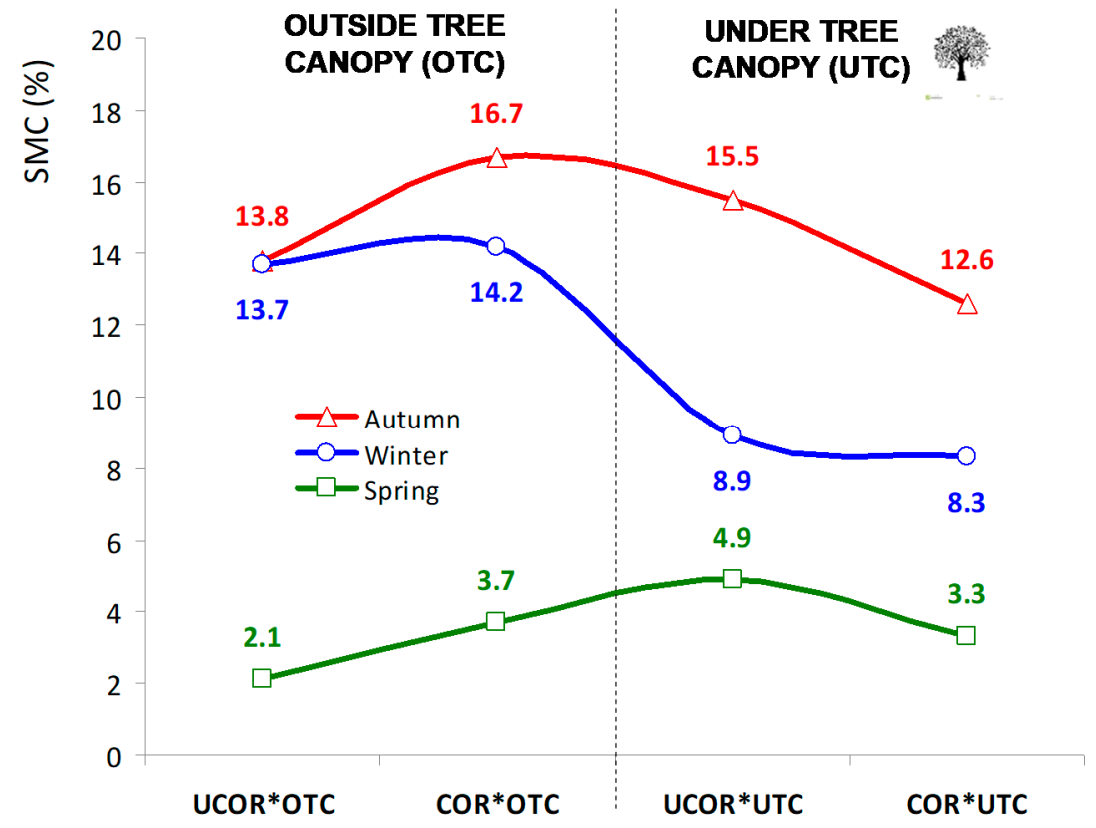

Figure 9. Pattern of average soil moisture content (SMC) in the $0-0.20 \mathrm{~m}$ layer during the vegetative cycle of pasture (corrected (COR) and uncorrected (UCOR) areas; and under tree canopy (UTC) and outside tree canopy (OTC) areas).

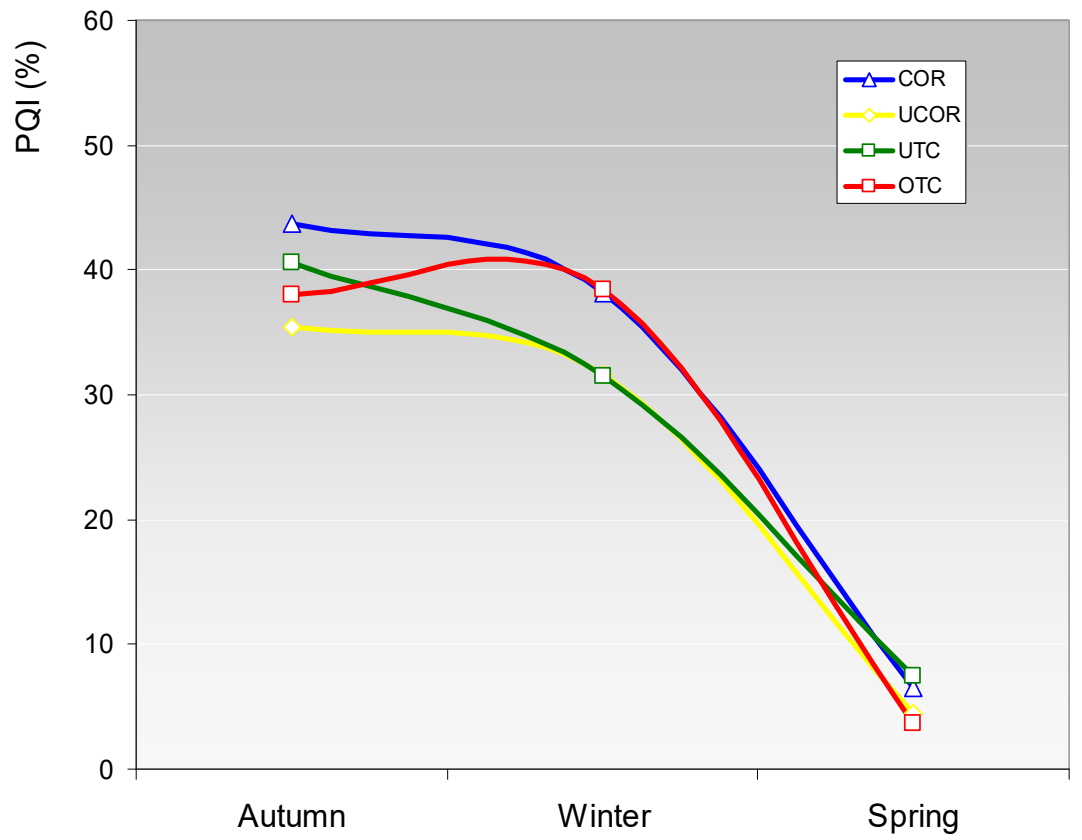

Figure 10. Evolution of the pasture quality index (PQI) during the vegetative cycle (corrected (COR) and uncorrected (UCOR) areas; and under tree canopy (UTC) and outside tree canopy (OTC) areas).

PQI, PMC, CP, and NDF, expressed in percent of DM, are pasture qualitative indicators. Monitoring of pasture quality over time is critical to define the nutritional value of pastures and design balanced diets for grazing animals [30]. However, these qualitative parameters do not take into account the evolution of DM. Calculation of the CP of the experimental field, in absolute terms (in $\mathrm{kg} \cdot \mathrm{ha}^{-1} \mathrm{based}^{-}$ on Equation (1)), quantifies the CP that is truly available at each moment (in this case at the end of each season: autumn, winter and spring). Figure 11 shows the DM (Figure 11a) and CP (Figure 11b) accumulated in each season (both in $\mathrm{kg} \cdot \mathrm{ha}^{-1}$ and as a percentage of accumulated total). While the DM production peak takes place in the spring (between $38.8 \%$ and $58.9 \%$ of accumulated total, depending 
on the specific area of the field), the $\mathrm{CP}$ availability is equally distributed among the three seasons, with a slight preponderance in winter. This approach is more appropriate since it allows the agricultural manager to have an idea of the effective $\mathrm{CP}$ availability per hectare. This indicator is much more stable throughout the pasture vegetative cycle (Figure 12) because it is based on two complementary parameters (while $\mathrm{CP}$ in percent tends to decrease during the vegetative cycle, $\mathrm{DM}$ in $\mathrm{kg} \cdot \mathrm{ha}^{-1}$ tends to increase) and, therefore, responds better to the food need of grazing animals (without resorting to supplementation).
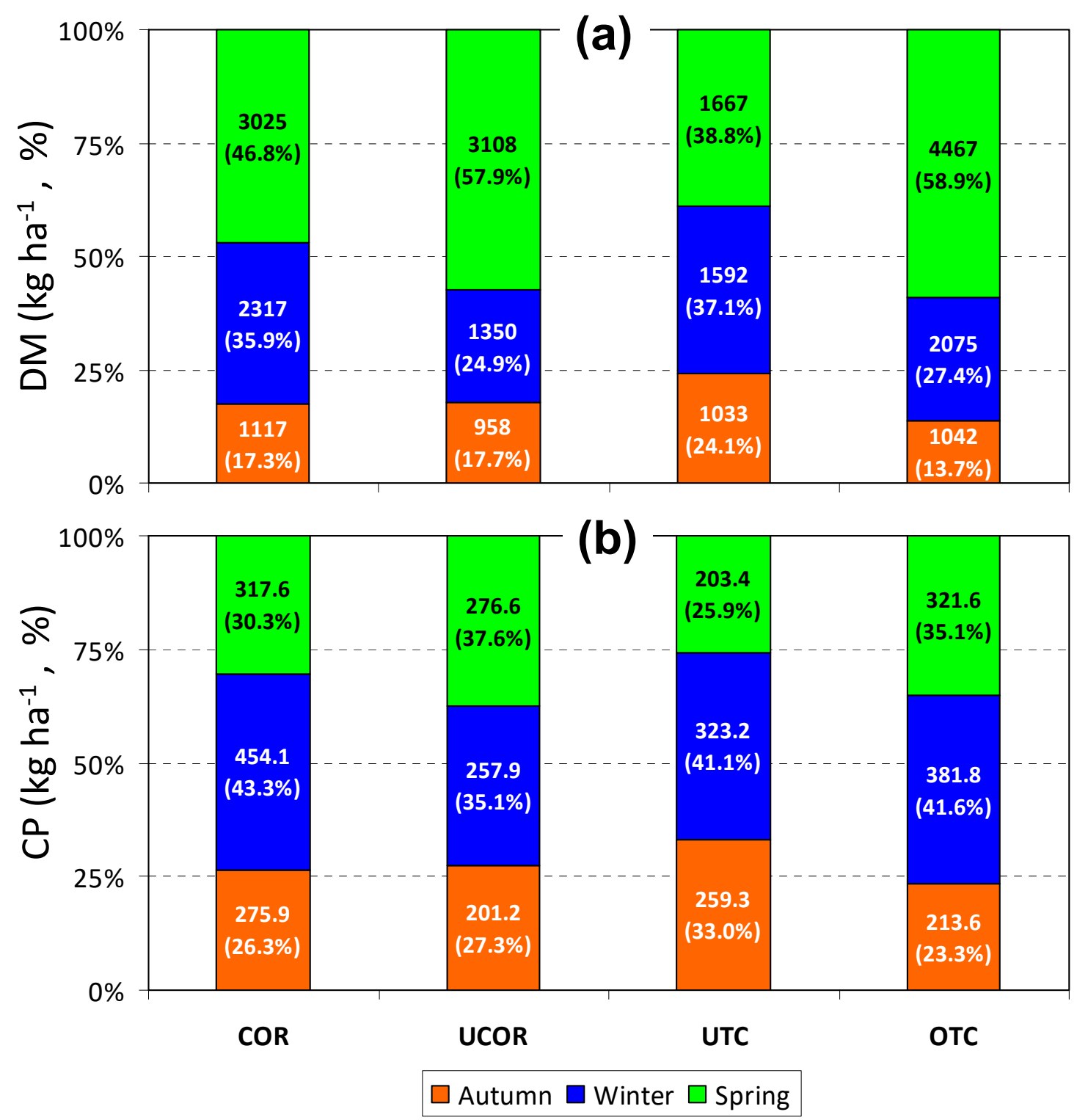

Figure 11. Evolution of: (a) pasture dry matter yield (DM); and (b) pasture crude protein (CP) accumulated in each season of the vegetative cycle, both in $\mathrm{kg} \cdot \mathrm{ha}^{-1}$ and as a percentage of total (corrected (COR) and uncorrected (UCOR) areas; and under tree canopy (UTC) and outside tree canopy (OTC) areas). 


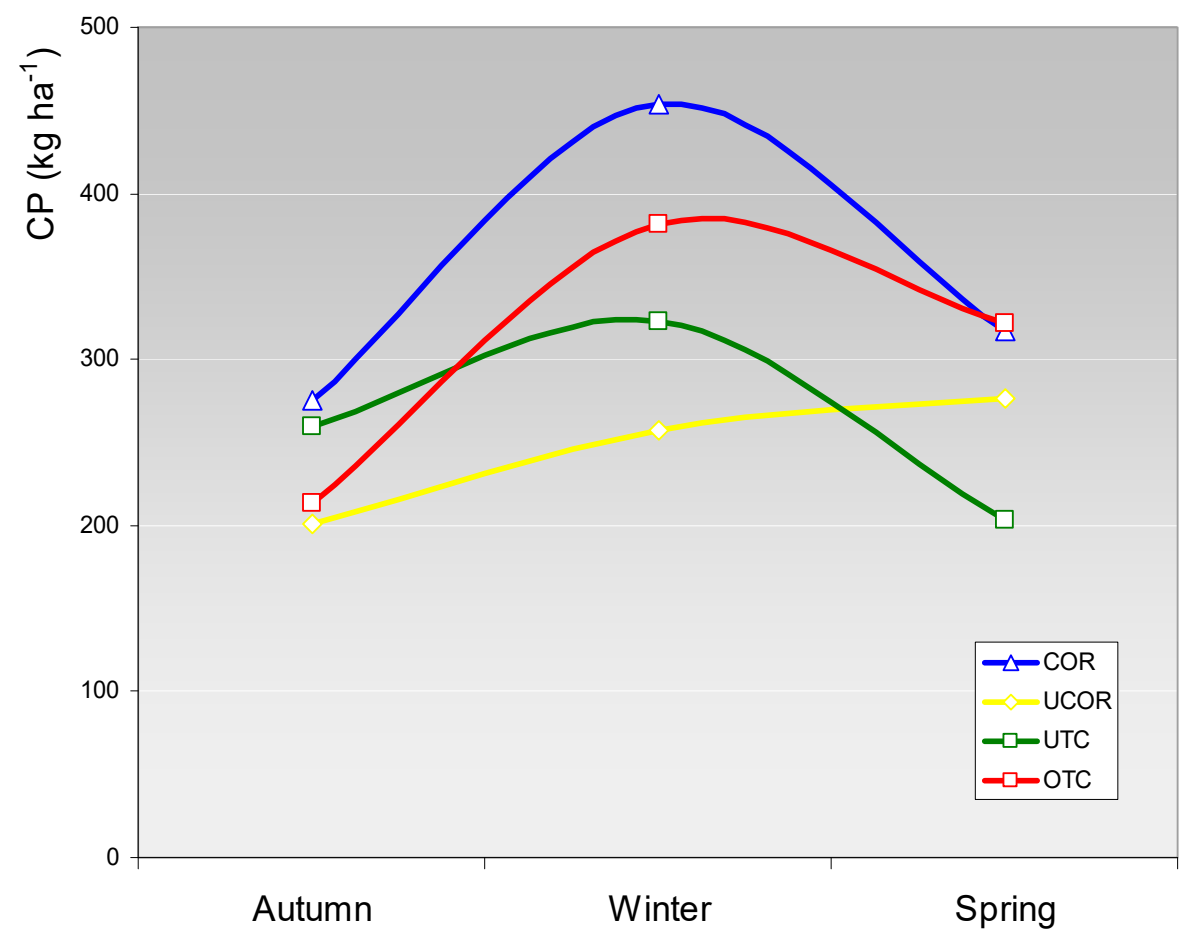

Figure 12. Evolution of pasture crude protein availability $\left(\mathrm{CP}, \mathrm{in} \mathrm{kg} \cdot \mathrm{ha}^{-1}\right)$ during the vegetative cycle (corrected (COR) and uncorrected (UCOR) areas; and under tree canopy (UTC) and outside tree canopy (OTC) areas).

In Figure 11, it is possible to observe the increased CP $\left(\mathrm{kg} \cdot \mathrm{ha}{ }^{-1}\right)$ production in COR areas (275.9, 454.1 , and $317.6 \mathrm{~kg} \cdot \mathrm{ha}^{-1}$, respectively, in autumn, winter, and spring) relative to UCOR areas (201.2, 257.9 , and $276.6 \mathrm{~kg} \cdot \mathrm{ha}^{-1}$, respectively, in autumn, winter, and spring). According to Crusciol et al. [25] and Halim et al. [26], this yield improvement provided by the surface lime application results from a positive effect on the soil nutritional condition, which is reflected in plant nutrition and chlorophyll content.

The tree canopy effect on pasture is a direct consequence of the extent to which they modify the microclimate and soil properties [6]. In particular, this effect in pasture CP (Figure 11) was only advantageous in autumn, tending to have greater absolute availability of $\mathrm{CP}$ in OTC areas in winter and spring due to the marked growth in productivity (DM) in these areas. A reduction in the quantity and quality of light UTC affects directly the physiological processes of plants, decreasing pasture carbohydrate manufacture and net DM production [6].

\section{Conclusions}

This study showed that amendment of soil acidity based on dolomitic lime application is a slow and gradual process that improves soil $\mathrm{Mg} / \mathrm{Mn}$ ratio and has a positive impact on pasture productivity and quality. Improving soil fertility and, consequently, pasture productivity/quality is a fundamental strategy that promotes greater sustainability of livestock production in two ways: (i) incorporation of organic matter, reducing the risks of soil degradation processes; and (ii) intensification of animal production systems, allowing higher number of animals per hectare and reducing the animals' need for supplementary feeding during critical periods. Pasture crude protein availability $\left(\mathrm{CP}\right.$, in $\left.\mathrm{kg} \cdot \mathrm{ha}^{-1}\right)$, since it is based on both pasture productivity $\left(\mathrm{DM}\right.$, in $\left.\mathrm{kg} \cdot \mathrm{ha}{ }^{-1}\right)$ and quality $(\mathrm{CP}$, in \%), proved to be a very practical indicator of the contributions of tree canopy and soil acidity correction to the holistic management of the Montado ecosystem. In the future, the common practice of phosphate fertilizer application in these acid soils of Mediterranean region to improve pasture productivity and quality must be complemented with previous and repeated application of dolomitic lime. In the context of 
climate change, the evaluation of the pasture biodiversity through floristic composition patterns will be fundamental for monitoring the adoption of the recommended management practices.

Author Contributions: J.S. ( $\approx 30 \%)$ : Conceptualization; formal analysis; funding acquisition, investigation, methodology, supervision, and writing. S.S. $(10 \%)$ : Conceptualization, review, and editing. J.M.d.S. $(\approx 10 \%)$ : Conceptualization and formal analysis. F.M. ( $\approx 10 \%)$ : Investigation. F.C.-R. $(10 \%)$ : Investigation. E.C. $(\approx 10 \%)$ : Investigation and methodology. A.P. ( $\approx 10 \%)$ : Investigation and methodology. M.d.C. $(\approx 10 \%)$ : Conceptualization, formal analysis, and methodology. All authors have read and agreed to the published version of the manuscript.

Funding: This work was funded by National Funds through FCT (Foundation for Science and Technology) under the Project UIDB/05183/2020 and by the projects PDR2020-101-030693 and PDR2020-101-031244 ("Programa 1.0.1-Grupos Operacionais").

Acknowledgments: The authors would like to express their sincere appreciation to Eliana Machado, of Mediterranean Institute for Agriculture, Environment and Development (MED), for their support in floristic inventory of species present in pasture of the experimental field.

Conflicts of Interest: The authors declare no conflict of interest.

\section{References}

1. IUSS Working Group WRB. World Reference Base for Soil Resources 2014; International Soil Classification System for Naming Soils and Creating Legends for Soil Maps. Update 2015; World Soil Resources Report 106; Food and Agriculture Organization (FAO): Rome, Italy, 2015; 188p.

2. Carvalho, M.; Goss, M.J.; Teixeira, D. Manganese toxicity in Portuguese Cambisols derived from granitic rocks: Causes, limitations of soil analyses and possible solutions. Rev. Cienc. Agrárias 2015, 38, 518-527. [CrossRef]

3. Guevara-Escobar, A.; Kemp, P.D.; Mackay, A.D.; Hodgson, J. Pasture production and composition under poplar in a hill environment in New Zealand. Agrofor. Syst. 2007, 3, 199-213. [CrossRef]

4. Efe Serrano, J. Pastures in Alentejo: Technical Basis for Characterization, Grazing and Improvement; Universidade de Évora-ICAM, Ed.; Gráfica Eborense: Évora, Portugal, 2006; pp. 165-178.

5. David, T.S.; Pinto, C.A.; Nadezhdina, N.; Kurz-Besson, C.; Henriques, M.O.; Quilhó, T.; Cermak, J.; Chaves, M.M.; Pereira, J.S.; David, J.S. Root functioning, tree water use and hydraulic redistribution in Quercus suber trees: A modeling approach based on root sap flow. For. Ecol. Manag. 2013, 307, $136-146$. [CrossRef]

6. Benavides, R.; Douglas, G.B.; Osoro, K. Silvopastoralism in New Zealand: Review of effects of evergreen and deciduous trees on pasture dynamics. Agrofor. Syst. 2009, 76, 327-350. [CrossRef]

7. Jackson, J.; Ash, A.J. Tree-grass relationships in open eucalypt woodlands of northeastern Australia: Influence of trees on pasture productivity, forage quality and species distribution. Agrofor. Syst. 1998, 40, 159-176. [CrossRef]

8. Pullanagari, R.R.; Yule, I.J.; Tuohy, M.P.; Hedley, M.J.; Dynes, R.A.; King, W.M. Proximal sensing of the seasonal variability of pasture nutritive value using multispectral radiometry. Grass Forage Sci. 2013, 68, 110-119. [CrossRef]

9. Serrano, J.; Shahidian, S.; Marques da Silva, J.; Paixão, L.; Carreira, E.; Pereira, A.; Carvalho, M. Climate changes challenges to the management of Mediterranean montado ecosystem: Perspectives for use of precision agriculture technologies. Agronomy 2020, 10, 218. [CrossRef]

10. Bonetti, R.; Oliveira, L.A.; Magalhães, F.M. População de rhizobium spp. e ocorrência de micorriza v.a. em cultivos de essências florestais. Pesqui. Agropecuária Bras. 1984, 19, 137-142.

11. Serrano, J.; Shahidian, S.; Marques da Silva, J. Monitoring seasonal pasture quality degradation in the Mediterranean montado ecosystem: Proximal versus remote sensing. Water 2018, 10, 1422. [CrossRef]

12. Serrano, J.; Shahidian, S.; Marques da Silva, J.; Sales-Baptista, E.; Ferraz de Oliveira, I.; Lopes de Castro, J.; Pereira, A.; Cancela d'Abreu, M.; Machado, E.; Carvalho, M. Tree influence on soil and pasture: Contribution of proximal sensing to pasture productivity and quality estimation in montado ecosystems. Int. J. Remote Sens. 2018, 39, 4801-4829. [CrossRef]

13. Egner, H.; Riehm, H.; Domingo, W.R. Utersuchungeniiber die chemische Bodenanalyse als Grudlagefir die Beurteilung des Nahrstof-zunstandes der Boden. II. K. Lantbrhogsk. Annlr 1960, 20, 199-216. (In German) 
14. AOAC. Official Method of Analysis of AOAC International, 18th ed.; AOAC International: Arlington, AT, USA, 2005.

15. Nawar, S.; Corstanje, R.; Halcro, G.; Mulla, D.; Mouazen, A.M. Delineation of soil management zones for variable-rate fertilization: A review. Adv. Agron. 2017, 143, 175-245.

16. Marques da Silva, J.R.; Peça, J.O.; Serrano, J.M.; Carvalho, M.J.; Palma, P.M. Evaluation of spatial and temporal variability of pasture based on topography and the quality of the rainy season. Precis. Agric. 2008, 9, 209-229. [CrossRef]

17. Serrano, J.; Shahidian, S.; Marques da Silva, J.; Paixão, L.; Calado, J.; Carvalho, M. Integration of soil electrical conductivity and indices obtained through satellite imagery for differential management of pasture fertilization. AgriEngineering 2019, 1, 41. [CrossRef]

18. Moral, F.; Terrón, J.; da Silva, J.M. Delineation of management zones using mobile measurements of soil apparent electrical conductivity and multivariate geostatistical techniques. Soil Tillage Res. 2010, 106, 335-343. [CrossRef]

19. Moral, F.J.; Serrano, J.M. Using low-cost geophysical survey to map soil properties and delineate management zones on grazed permanent pastures. Precis. Agric. 2019, 20, 1000-1014. [CrossRef]

20. Seddaiu, G.; Porcua, G.; Luigi, L.; Roggero, P.P.; Agnelli, A.; Cortic, G. Soil organic matter content and composition as influenced by soil management in a semi-arid Mediterranean agro-silvo-pastoral system. Agric. Ecosyst. Environ. 2013, 167, 1-11. [CrossRef]

21. Martins, A.P.; Cecagno, D.; Borin, J.B.M.; Arnuti, F.; Lochmann, S.H.; Anghinoni, I.; Bissani, C.A.; Bayer, C.; Carvalho, P.C.F. Long-, medium- and short-term dynamics of soil acidity in an integrated crop-livestock system under different grazing intensities. Nutr. Cycl. Agroecosyst. 2016, 104, 67-77. [CrossRef]

22. Lal, R. Restoring soil quality to mitigate soil degradation. Sustainability 2015, 7, 5875-5895. [CrossRef]

23. Noumonvi, K.D.; Ferlan, M.; Eler, K.; Alberti, G.; Perossotti, A.; Cerasoli, S. Estimation of Carbon Fluxes from Eddy Covariance Data and Satellite-Derived Vegetation Indices in a Karst Grassland (Podgorski Kras, Slovenia). Remote Sens. 2019, 11, 649. [CrossRef]

24. Rodrigues, A.R.; Costa e Silva, F.; Correia, A.C.; Bicho, M.C.; Madeira, M. Do improved pastures enhance soil quality of cork oak woodlands in the Alentejo region (Portugal)? Agrofor. Syst. 2020, 94, 125-136. [CrossRef]

25. Crusciol, C.A.; Marques, R.R.; Carmeis Filho, A.C.; Soratto, R.P.; Costa, C.H.; Neto, J.F.; Castro, G.S.; Pariz, C.M.; Castilhos, A.M.; Franzluebbers, A.J. Lime and gypsum combination improves crop and forage yields and estimated meat production and revenue in a variable charge tropical soil. Nutr. Cycl. Agroecosyst. 2019, 115, 347-372. [CrossRef]

26. Halim, N.; Abdullah, R.; Karsani, S.; Osman, N.; Panhwar, Q.; Ishak, C. Influence of soil amendments on the growth and yield of rice in acidic soil. Agronomy 2018, 8, 165. [CrossRef]

27. Li, G.D.; Conyers, M.K.; Helyar, K.R.; Lisle, C.J.; Poile, G.J.; Cullis, B.R. Long-term surface application of lime ameliorates subsurface soil acidity in the mixed farming zone of south-eastern Australia. Geoderma 2019, 338, 236-246. [CrossRef]

28. Bernardi, A.C.C.; Bueno, J.O.A.; Laurenti, N.; Santos, K.E.L.; Alves, T.C. Efeito da calagem e fertilizantes aplicados à taxa variável nos atributos químicos do solo e custos de produção de pastagem de Capim Tanzânia manejadas intensivamente. Braz. J. Biosyst. Eng. 2018, 12, 368-382. [CrossRef]

29. Gubler, A.; Wächter, D.; Schwab, P.; Müller, M.; Keller, A. Twenty-five years of observations of soil organic carbon in Swiss croplands showing stability overall but with some divergent trends. Environ. Monit. Assess. 2019, 191, 277. [CrossRef]

30. Demanet, R.; Mora, M.L.; Herrera, M.A.; Miranda, H.; Barea, J.M. Seasonal variation of the productivity and quality of permanent pastures in Adisols of temperate regions. J. Soil Sci. Plant Nut. 2015, 15, 111-128. [CrossRef]

(C) 2020 by the authors. Licensee MDPI, Basel, Switzerland. This article is an open access article distributed under the terms and conditions of the Creative Commons Attribution (CC BY) license (http://creativecommons.org/licenses/by/4.0/). 